\title{
ANALISIS PERSEPSI SISWA TERHADAP PEMBELAJARAN FISIKA BERBASIS ECOPEDAGOGY DENGAN METODE DARING SELAMA PANDEMI COVID-19
}

\author{
Diyah Ayu Octa Nova1), Dwikoranto ${ }^{1)}$, Nurita Apridiana Lestari'1) \\ 1)Program Studi Pendidikan Fisika, FMIPA, Universitas Negeri Surabaya, Surabaya, Jawa Timur, Indonesia \\ Corresponding author: Diyah Ayu Octa Nova \\ E-mail : diyah.17030184048@mhs.unesa.ac.id
}

Diterima 25 Februari 2021, Direvisi 05 Maret 2021, Disetujui 08 Maret 2021

\begin{abstract}
ABSTRAK
Penelitian ini adalah studi awal untuk menganalisis persepsi siswa terhadap pembelajaran fisika berbasis ecopedagogy dengan metode daring. Pembelajaran fisika berbasis ecopedagogy dilakukan untuk menumbuhkan kesadaran atau kepedulian lingkungan serta memecahkan permasalahan lingkungan berdasarkan konsep fisika. Penelitian ini menggunakan metode survey dengan teknik pengumpulan data berupa angket. Responden yang diperoleh pada penelitian ini sebanyak 97 orang dari kelas 10, 11, dan 12 yang bersekolah di wilayah Sidoarjo. Berdasarkan penelitian yang telah dilakukan dapat disimpulkan bahwa persepsi siswa terhadap pembelajaran fisika berbasis ecopedagogy adalah positif. Siswa tertarik dengan pembelajaran ini. Siswa juga menyatakan bahwa pembelajaran fisika berbasis ecopedagogy penting untuk dilakukan. Hal ini karena pembelajaran fisika berbasis ecopedagogy dilakukan dengan tujuan agar siswa dapat menyelesaikan berbagai permasalahan lingkungan berdasarkan konsep fisika yang dipahami. Selain itu, pembelajaran ini juga dapat menumbuhkan kesadaran atau sikap peduli lingkungan.
\end{abstract}

Kata kunci: persepsi siswa; pembelajaran daring; ecopedagogy; kesadaran lingkungan

\begin{abstract}
This study is a preliminary study to analyze students' perception of ecopedagogy-based physics learning with online methods. Ecopedagogy-based physics learning is done to raise awareness or environmental concern and solve environmental problems based on the concept of physics. This research uses survey method with data collection techniques in the form of questionnaires. Respondents obtained in this research were 97 people from grades 10,11, and 12 in the Sidoarjo. Based on the research, it can be concluded that students' perception of ecopedagogy-based physics learning is positive. Students are interested in this learning. Students also stated that ecopedagogy-based physics learning is important to do. This is because ecopedagogy-based physics learning is done with the aim that students can solve environmental problems based on the concept of physics. In addition, this learning can also raise environmental awareness.
\end{abstract}

Keywords: students' perception; online learning; ecopedagogy; environmental awareness

\section{PENDAHULUAN}

Pada awal tahun 2020 seluruh dunia dikejutkan dengan merebaknya wabah virus covid-19 yang berdampak cukup besar pada kehidupan manusia. Pemerintah mengeluarkan kebijakan dalam rangka mencegah penyebaran covid-19 ini seperti dengan pemberlakuan social distancing, memakai masker di tempat terbuka, dan selalu cuci tangan mengunakan sabun (Sadikin \& Hamidah, 2020). Pandemi covid-19 juga berdampak besar bagi dunia pendidikan yang mengharuskan adanya perubahan sistem pembelajaran yang biasanya dilakukan secara tatap muka terpaksa harus diganti dengan pembelajaran daring (Allo, 2020; Napsawati, 2020).
Pembelajaran daring adalah sebuah kegiatan pembelajaran yang menggunakan media pembelajaran interaktif serta mengelola konten yang diberikan kepada siswa dengan tujuan untuk meningkatkan kualitas pembelajaran (Chang \& Fang, 2020). Pada pelaksanaan pembelajaran daring, guru dan siswa menggunakan media pembelajaran yang memungkinkan terjadinya proses dan interaksi dalam kegiatan pembelajaran walaupun berada di tempat yang berbeda. Kini banyak media pembelajaran yang dapat digunakan untuk menunjang dan mempermudah proses pembelajaran. Namun, pembelajaran daring membutuhkan fasilitas yang memadai serta kondisi internet yang bagus untuk memudahkan komunikasi antara guru dan siswa selama 
proses pembelajaran (Purwanto et al., 2020). Kegiatan pembelajaran daring menjadi tantangan yang harus dihadapi di era revolusi industri 4.0, karena pemanfaatan teknologi digital dalam kegiatan pembelajaran merupakan salah satu ciri dari era ini (Dewa et al., 2020; Lase, 2019). Perkembangan teknologi yang ada kini diharapkan dapat membuat pelaksanaan pembelajaran daring berjalan dengan baik dan maksimal. Selain itu, media pembelajaran yang dapat digunakan juga semakin bervariasi. Oleh karena itu guru diharapkan harus tetap kreatif dalam menyajikan pembelajaran agar siswa tertarik, terutama pada pembelajaran fisika yang seringkali dianggap sebagai mata pelajaran yang sulit (Samudra et al., 2014).

Fisika sebagai ilmu alam mempelajari berbagai fenomena yang terjadi di lingkungan sekitar dan dikaji secara fisis. Fisika merupakan suatu ilmu yang berperan besar dalam memahami lingkungan. Ilmu ini memiliki peran penting dalam memahami kondisi lingkungan karena berbagai permasalahan lingkungan seperti pemanasan global, polusi, bahkan eksploitasi sumber daya alam (Napitupulu, 2015). Oleh karena itu penting adanya pemahaman dasar fisika agar tidak terjadi eksploitasi sumber energi maupun penyalahgunaan sumber energi yang dapat berakibat buruk terhadap lingkungan. Lingkungan sebagai suatu sistem yang kompleks memiliki peran penting dalam kehidupan manusia karena apabila lingkungan mengalami kerusakan, maka akan berdanpak pada kehidupan manusia yang terancam ikut terganggu. Manusia dan lingkungan saling berhubungan karena manusia merupakan salah satu penyebab terjadinya perubahan kondisi lingkungan. Perubahan kondisi lingkungan menjadi lebih buruk disebut sebagai permasalahan lingkungan (Agfar et al., 2018).

Permasalahan lingkungan muncul karena gaya hidup masyarakat yang tidak selaras dengan lingkungan dan kurangnya kesadaran lingkungan (Khanafiyah \& Yulianti, 2013). Beberapa faktor yang diduga menjadi penyebab munculnya permasalahan lingkungan diantaranya penggundulan hutan, penggunaan energi yang boros, dan berbagai kegiatan lain yang dilakukan manusia yang dapat memicu terjadinya degradasi lingkungan (Napitupulu et al., 2019). Degradasi lingkungan merupakan suatu kondisi penurunan kualitas lingkungan. Degradasi lingkungan juga mengacu pada rusaknya alam serta terganggunya ekosistem yang ada di dalamnya. Degradasi lingkungan merupakan salah satu salah satu bentuk permasalahan lingkungan. Sulit untuk mengatasi permasalahan lingkungan apabila masyarakat tidak memiliki tanggung jawab dan kepedulian terhadap lingkungan (Suryanti et al., 2018). Oleh karena itu tiap individu penting untuk memiliki rasa tanggung jawab dan sikap peduli lingkungan.

Menumbuhkan sikap peduli lingkungan bukanlah hal yang mudah dan cepat untuk dilakukan. Salah satu solusi yang dapat dilakukan dalam rangka mencegah dan mengatasi permasalahan lingkungan yaitu melalui jalur pendidikan seperti pendidikan lingkungan (Sukma et al., 2020). Pendidikan lingkungan didefinisikan sebagai sebuah proses yang dilakukan dalam rangka mengembangkan kemampuan serta etika individu untuk memahami hubungan antara manusia dengan lingkungan (Febriasari \& Supriatna, 2017). Pendidikan lingkungan dilakukan untuk menyadarkan individu terhadap isu-isu lingkungan dan memahami bahwa setiap tindakan yang dilakukan akan berpengaruh terhadap lingkungan (Napitupulu, 2015). Tercapainya tujuan pendidikan lingkungan dapat dilihat dari beberapa indikator diantaranya yaitu adanya perubahan positif individu dalam hal etika lingkungan, pengetahuan lingkungan, kepedulian lingkungan, serta gaya hidup atau perilaku yang selaras dengan lingkungan (Yalmanci \& Gözüm, 2019). Salah satu pendidikan lingkungan yang dapat dilakukan di sekolah yaitu kegiatan pembelajaran berbasis ecopedagogy.

Ecopedagogy merupakan sebuah gerakan yang bertujuan untuk membangun kesadaran ekologis sehingga individu diharapkan memiliki pemahaman dan kesadaran dalam membangun gaya hidup yang selaras dengan lingkungan (Yunansah \& Herlambang, 2017). Ecopedagogy juga bertujuan untuk memberikan pengetahuan kepada siswa mengenai cara mengatasi permasalahan lingkungan yang bersifat kontemporer dan juga yang akan terjadi di masa depan seperti pencemaran, perubahan iklim, penipisan lapisan ozon, dan lain sebagainya, sehingga adanya ecopedagogy dapat mengatasi beberapa permasalahan terkait lingkungan yang dapat berdampak pada kehidupan manusia (Grigorov \& Fleuri, 2012). Selain itu, adanya pembelajaran berbasis ecopedagogy dapat membuat siswa sadar terhadap berbagai permasalahan yang terjadi di lingkungan serta mengetahui berbagai tindakan yang berpengaruh terhadap lingkungan (Napitupulu \& Munandar, 2017). Oleh karena itu, melalui pembelajaran fisika berbasis ecopedagogy diharapkan bahwa siswa dapat memahami dan menyelesaikan permasalahan lingkungan dengan pengetahuan dan keterampilan yang dimiliki. 
Berdasarkan penelitian yang dilakukan Napitupulu (2015) bahwa pembelajaran ecophysics berbasis ecopedagogy terbukti dapat menumbuhkan sikap ekologis calon guru fisika. Pembelajaran ecophysic yang dimaksud diantaranya meliputi pemanasan global, energi terbarukan, dan polusi. Penelitian lain yang dilakukan Okur-Berberoglu (2017) menyatakan bahwa Ecopedagogy-Based Outdoor Experiential Education (EOEE) berhasil meningkatkan kesadaran lingkungan. Penelitian yang juga dilakukan Napitupulu \& Munandar (2017) menyatakan bahwa melalui Inquiry Based Ecopedagogy (In-EcoP) terbukti dapat meningkatkan motivasi dan hasil belajar mahasiswa calon guru fisika. Berdasarkan pemaparan pendahuluan, penelitian ini dilakukan dengan tujuan untuk menganalisis persepsi siswa terhadap pembelajaran fisika berbasis ecopedagogy dengan metode daring.

\section{METODE PENELITIAN}

Jenis penelitian ini menggunakan penelitian deskriptif dengan metode survey. Pengumpulan data menggunakan angket yang disebarkan kepada beberapa siswa yang bersekolah di wilayah Sidoarjo. Penyebaran angket dilakukan secara online melalui media komunikasi whatsapp kepada siswa SMA kelas 10, 11, dan 12 jurusan MIPA. Angket yang disebarkan berisi sejumlah pertanyaan untuk menggali informasi awal mengenai persepsi siswa terhadap kegiatan pembelajaran fisika selama pandemi covid-19 di wilayah Sidoarjo. Selain itu juga disajikan beberapa pertanyaan yang bertujuan untuk mengetahui persepsi siswa terhadap pembelajaran fisika berbasis ecopedagogy. Angket yang disebarkan berbentuk link yang terhubung dengan google form yang berisi 13 pertanyaan beserta alasan yang mendasari jawaban dari pertanyaan tersebut. Penentuan persentase hasil angket diperoleh melalui persen diagram lingkaran yang dihasilkan dari respon masing-masing pertanyaan yang diajukan di google form. Hasil penelitian ini berupa analisis deskriptif mengenai persepsi siswa terhadap pembelajaran fisika berbasis ecopedagogy serta pelaksanaan kegiatan pembelajaran yang dilakukan secara daring.

\section{HASIL DAN PEMBAHASAN}

Angket yang disebarkan kepada siswa memperoleh 97 responden yang berasal dari kelas 10, 11, dan 12 dari berbagai sekolah di wilayah Sidoarjo. Berikut adalah hasil yang diperoleh (Tabel 1) berdasarkan angket yang telah disebarkan.
Tabel 1. Hasil Angket Persepsi Siswa Terhadap Pembelajaran Fisika

\begin{tabular}{|c|c|c|}
\hline Pernyataan & Ya & Tidak \\
\hline $\begin{array}{lr}\text { Pelajaran } & \text { fisika } \\
\text { menarik } & \text { dan } \\
\text { menyenangkan } & \end{array}$ & $77,3 \%$ & $22,7 \%$ \\
\hline $\begin{array}{lr}\text { Saya } & \text { kesulitan } \\
\text { memahami } & \text { materi } \\
\text { fisika } & \\
\end{array}$ & $80,4 \%$ & $19,6 \%$ \\
\hline $\begin{array}{l}\text { Saya kesulitan dalam } \\
\text { pembelajaran daring }\end{array}$ & $63,9 \%$ & $36,1 \%$ \\
\hline $\begin{array}{lr}\text { Pembelajaran } & \text { fisika } \\
\text { yang dilakukan selalu } \\
\text { dikaitkan dengan } \\
\text { fenomenar dalam } \\
\text { kehidupan sehari-hari }\end{array}$ & $83,5 \%$ & $16,5 \%$ \\
\hline $\begin{array}{l}\text { Saya mengetahui } \\
\text { contoh konsep fisika } \\
\text { yang terkait dengan } \\
\text { fenomena lingkungan } \\
\text { di sekitar }\end{array}$ & $66 \%$ & $34 \%$ \\
\hline $\begin{array}{lr}\text { Guru } & \text { pernah } \\
\text { mengajak untuk } \\
\text { memecahkan } \\
\text { permasalahan terkait } \\
\text { fenomena di sekitar } \\
\text { dalam kegiatan } \\
\text { pembelajaran fisika }\end{array}$ & $50,5 \%$ & $49,5 \%$ \\
\hline $\begin{array}{l}\text { Saya tertarik dengan } \\
\text { isu-isu/permasalahan } \\
\text { lingkungan yang } \\
\text { tengah terjadi }\end{array}$ & $56,7 \%$ & $43,3 \%$ \\
\hline $\begin{array}{ll}\text { Saya tertarik dengan } \\
\text { pembelajaran fisika } \\
\text { terintegrasi } \\
\text { pendidikan } \\
\text { lingkungan }\end{array}$ & $82,5 \%$ & $17,5 \%$ \\
\hline $\begin{array}{l}\text { Pembelajaran fisika } \\
\text { terintegrasi } \\
\text { pendidikan } \\
\text { lingkungan penting } \\
\text { untuk dipelajari }\end{array}$ & $86,6 \%$ & $13,4 \%$ \\
\hline $\begin{array}{lr}\text { Saya } & \text { pernah } \\
\text { mendengar } & \text { istilah } \\
\text { ekologi } & \\
\end{array}$ & $56,7 \%$ & $43,3 \%$ \\
\hline $\begin{array}{lr}\text { Saya } & \text { pernah } \\
\text { mendengar } & \text { istilah } \\
\text { ecopedagogy } & \end{array}$ & $12,4 \%$ & $87,6 \%$ \\
\hline $\begin{array}{l}\text { Saya memiliki sikap } \\
\text { peduli lingkungan }\end{array}$ & $94,8 \%$ & $5,2 \%$ \\
\hline $\begin{array}{lr}\text { Sikap } & \text { peduli } \\
\text { lingkungan } & \text { dapat } \\
\text { ditumbuhkan } & \text { melalui } \\
\text { kegiatan } & \\
\text { pembelajaran } & \end{array}$ & $93,8 \%$ & $6,2 \%$ \\
\hline
\end{tabular}

Berdasarkan Tabel 1, dapat diketahui bahwa $77,3 \%$ siswa tertarik dengan pelajaran fisika dan menganggap bahwa fisika adalah pelajaran yang menyenangkan dan sisanya 
menganggap tidak. Alasan yang dikemukakan siswa mengenai ketertarikan mereka pada mata pelajaran ini cukup beragam, diantaranya karena kegiatan pembelajaran, guru, praktikum, media pembelajaran, materi, dan soal. Berikut adalah persentase alasan ketertarikan siswa terhadap pembelajaran fisika.

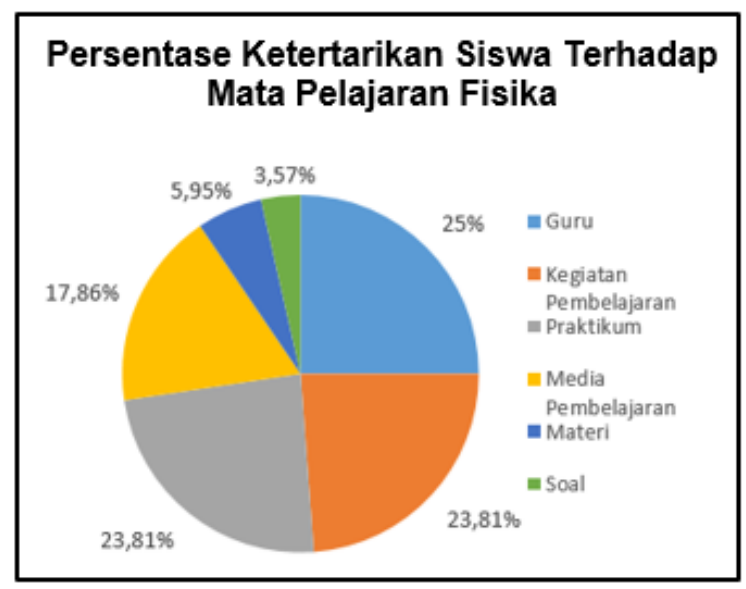

Gambar 1. Persentase ketertarikan siswa terhadap mata pelajaran fisika

Berdasarkan Gambar 1, faktor terbesar yang membuat siswa tertarik pada mata pelajaran fisika adalah guru dan kegiatan pembelajaran. Menurut mereka, apabila cara mengajar guru tidak menarik dan tidak menyenangkan akan membuat kurangnya minat siswa pada mata pelajaran fisika.

Pada Tabel 1 dapat diketahui bahwa sebagian besar siswa mengalami kesulitan dalam mempelajari serta memahami materi fisika. Adapun menghafal dan penerapan rumus menjadi salah satu aspek penyebab kesulitan yang dialami oleh sebagian besar siswa. Berikut beberapa jawaban siswa mengenai alasan kesulitan memahami materi fisika.

Tabel 2. Alasan Kesulitan Memahami Materi Fisika

\begin{tabular}{|c|c|}
\hline Siswa & Jawaban \\
\hline 1 & $\begin{array}{l}\text { Menentukan rumus yang } \\
\text { digunakan dalam mengerjakan } \\
\text { suatu soal }\end{array}$ \\
\hline 2 & $\begin{array}{l}\text { Menurut saya, banyak rumus } \\
\text { asing yang belum saya tahu, } \\
\text { kemudian pengaplikasiannya } \\
\text { membingungkan dan butuh } \\
\text { tingkat konsentrasi tinggi }\end{array}$ \\
\hline 3 & $\begin{array}{l}\text { Terkadang saya kesulitan } \\
\text { memahami rumusnya. Ketika } \\
\text { saya menghafal suatu rumus } \\
\text { fisika, rumus tersebut terkadang } \\
\text { berbeda untuk mencari jawaban } \\
\text { pada rumus itu tadi }\end{array}$ \\
\hline
\end{tabular}

Kesulitan terbesar yang dialami siswa dalam belajar fisika yaitu menentukan rumus yang digunakan ketika menyelesaikan soal. Pada umumnya siswa jarang melakukan analisis soal dan sekadar menebak dan menghafal rumus pada contoh soal yang diberikan guru, sehingga siswa akan mengalami kesulitan apabila disajikan soal dengan permasalahan yang lebih kompleks (Azizah et al., 2015). Berikut adalah persentase macam-macam bentuk soal yang sulit dikerjakan menurut siswa.

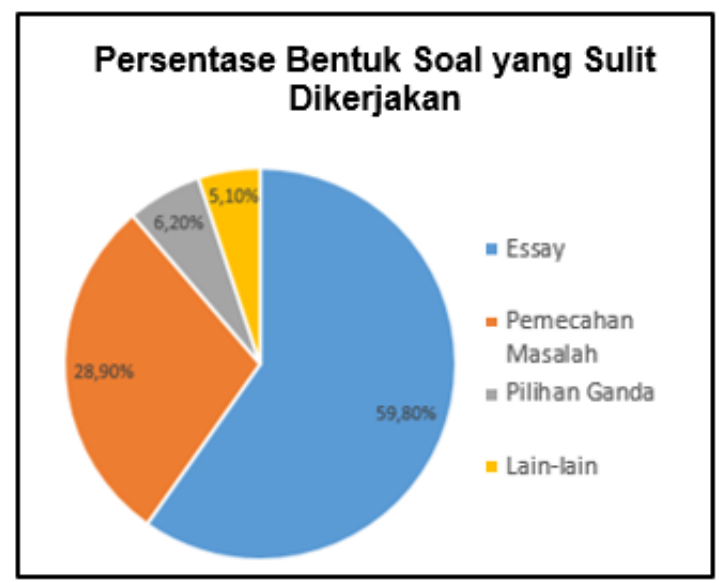

Gambar 2. Persentase bentuk soal yang sulit dikerjakan

Berdasarkan Gambar 2 diketahui bahwa bentuk soal essay merupakan bentuk soal yang paling sulit dikerjakan oleh siswa. Hal ini relevan dengan penelitian pada pembelajaran fisika SMP yang menggunakan instrumen tes berupa soal essay yang menjelaskan bahwa kesulitan yang dialami berupa kesulitan dalam berhitung, pemahaman konsep, mengartikan simbol dan mengkonversi satuan (Haqiqi \& Sa'adah, 2018). Sebagian besar siswa memilih bentuk soal essay karena pada soal sulit untuk memperkirakan jawaban yang benar, berbeda dengan bentuk soal pilihan ganda. Pada soal pilihan ganda siswa dapat menerka jawaban apabila kesulitan dalam mengerjakan soal. Berdasarkan hasil yang diperoleh, siswa yang memilih pilihan ganda sebagai soal yang sulit dikerjakan hanya sekitar $5,1 \%$. Alasan siswa yang memilih pilihan ganda karena bentuk soal ini sering menjebak apabila tidak teliti dalam mengerjakan. Adapun alasan yang dikemukakan siswa yang memilih bentuk soal pemecahan masalah hampir sama dengan siswa yang memilih essay. Siswa mengatakan bahwa bentuk soal ini memerlukan analisis yang lebih dalam untuk menyelesaikannya.

Siswa juga mengemukakan alasan lain yang berpengaruh terhadap kesulitan memahami materi fisika yaitu pada guru dan kegiatan pembelajaran. Hal ini relevan dengan penelitian yang menjelaskan bahwa faktor 
eksternal seperti metode pembelajaran yang dilakukan guru berpengaruh terhadap kesulitan belajar fisika (Arief et al., 2012). Guru cenderung melakukan kegiatan pembelajaran tanpa adanya praktik dan menggunakan metode ceramah. Pada metode ceramah, kegiatan pembelajaran akan berpusat pada guru dan siswa cenderung pasif. Siswa mengatakan bahwa sulit memahami materi yang disampaikan guru tanpa adanya praktik atau sekadar memahami teori. Hal ini sesuai dengan hasil penelitian yang diperoleh bahwa metode pembelajaran fisika yang paling sering digunakan yaitu metode ceramah. Persentase jenis-jenis metode pembelajaran yang sering digunakan guru pada pembelajaran fisika dapat dilihat pada Gambar 3.

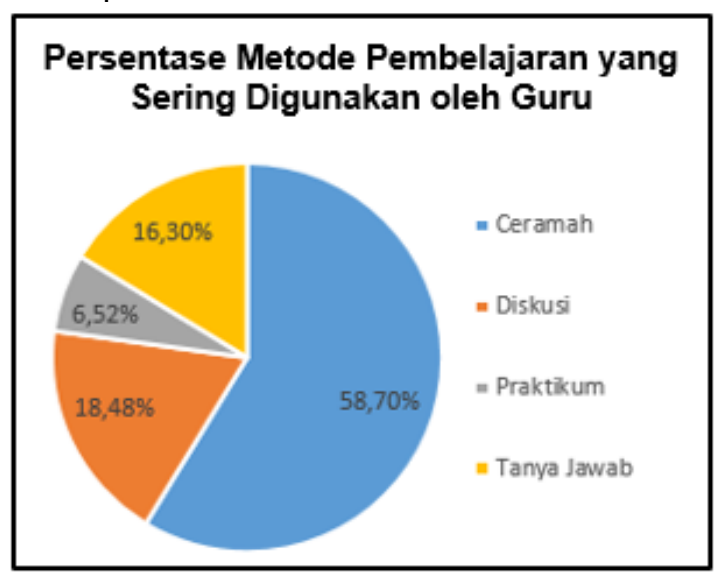

Gambar 3. Metode pembelajaran yang sering digunakan guru

Berdasarkan Gambar 3 dapat diketahui bahwa metode ceramah merupakan salah satu metode yang sering digunakan pada saat kegiatan pembelajaran daring. Beberapa siswa memiliki pendapat yang berbeda mengenai kegiatan pembelajaran daring yang telah mereka rasakan selama ini. Sebagian besar diantaranya menyatakan bahwa pembelajaran daring itu membosankan, tidak menyenangkan, dan tidak efektif. Siswa yang memilih alasan ini merasa lebih sulit memahami materi karena kendala jaringan, sehingga menganggu penyampaian materi pembelajaran oleh guru. Pada beberapa sekolah juga diberlakukan jam pelajaran yang dipersingkat, sehingga waktu untuk melakukan tanya jawab antara guru dan siswa berkurang. Siswa pun merasa bahwa mereka tidak leluasa bertanya kepada guru. Terkadang guru hanya memberi tugas tanpa disertai penjelasan materi. Siswa yang mengatakan pembelajaran daring menyenangkan dan efektif menyatakan alasan bahwa lebih mudah memahami materi yang diajarkan karena dapat mengulang materi melalui rekaman kegiatan pembelajaran. Keefektifan pembelajaran daring dapat dinilai dari cara guru dalam menyajikan pembelajaran yang tidak monoton, mudah dimengerti, dan menyenangkan sehingga siswa tidak mudah bosan selama kegiatan pembelajaran berlangsung (Napsawati, 2020).

Berdasarkan hasil angket yang diperoleh, sebagian besar siswa menjawab bahwa kegiatan pembelajaran fisika selalu dikaitkan dengan fenomena dalam kehidupan sehari-hari. Sekitar $66 \%$ diantaranya mampu menyebutkan beberapa contoh konsep fisika yang terjadi dalam kehidupan sehari-hari seperti jatuhnya buah dari pohon yang merupakan akibat dari gaya gravitasi, peristiwa perpindahan panas meliputi konduksi, konveksi, dan radiasi saat memasak, terbentuknya pelangi berdasarkan konsep pembiasan cahaya, dan lain sebagainya. Tujuan pembelajaran fisika tidak hanya sebatas memiliki pengetahuan konsep saja, tetapi juga mengembangkan kemampuan analisis siswa dalam menyelesaikan permasalahan di lingkungan sekitar (Azizah et al., 2015). Adapun untuk menyelesaikan permasalahan membutuhkan pemahaman hubungan antar konsep fisika yang matang (Trianggono, 2017). Sekitar 50,5\% siswa menyatakan bahwa guru telah mengajarkan pemecahan masalah pada pembelajaran fisika berdasarkan peristiwa yang terjadi dalam kehidupan sehari-hari. Salah satu contoh pemecahan masalah yang diajarkan guru yaitu siswa menganalisis pengaruh luas permukaan terhadap kematangan tahu. Siswa dikatakan memiliki kemampuan pemecahan masalah apabila setiap indikator pemecahan masalah polya terpenuhi (Hidayat et al., 2017). Indikator tersebut meliputi (1) memahami masalah, (2) menyusun rencana, (3) melaksanakan rencana, dan (4) mengevaluasi.

Fisika sebagai salah satu cabang ilmu alam memiliki cakupan bahasa yang erat kaitannya dengan lingkungan. Berdasarkan Tabel 1 dapat diketahui bahwa sebagian besar siswa mengetahui istilah ekologi. Siswa dapat menjelaskan definisi ekologi dengan benar, yaitu ilmu yang mempelajari interaksi makhluk hidup dengan lingkungannya Sekitar 56,7\% siswa mengatakan bahwa mereka tertarik dengan isu-isu/ permasalahan lingkungan. Beberapa permasalahan lingkungan yang diketahui diantaranya banjir, pemanasan global, pencemaran air karena limbah, polusi udara, dan lain sebagainya. Tumbuhnya kepedulian terhadap isu-isu lingkungan serta melihat besarnya pengaruh manusia terhadap bumi merupakan salah satu tujuan dari pembelajaran terintegrasi pendidikan lingkungan (Napitupulu, 2015). Kegiatan pembelajaran terintegrasi pendidikan lingkungan juga bertujuan untuk menumbuhkan sikap peduli lingkungan serta 
memberikan solusi terhadap permasalahan lingkungan yang dihadapi (Agfar et al., 2018). Sebanyak $82,5 \%$ siswa mengatakan bahwa mereka tertarik dengan kegiatan pembelajaran terintegrasi pendidikan lingkungan. Menurut mereka, pembelajaran terintegrasi pendidikan lingkungan penting untuk dilakukan. Berikut beberapa pernyataan siswa mengenai pentingnya pembelajaran terintegrasi pendidikan lingkungan.

Tabel 3. Alasan Pentingnya Pembelajaran Terintegrasi Pendidikan Lingkungan

\begin{tabular}{cl}
\hline Siswa & \multicolumn{1}{c}{ Jawaban } \\
\hline 1 & $\begin{array}{l}\text { Untuk menyelesaikan } \\
\text { permasalahan lingkungan yang } \\
\text { terjadi sehingga dapat mencegah } \\
\text { kerusakan-kerusakan di muka } \\
\text { bumi }\end{array}$ \\
\hline 2 & $\begin{array}{l}\text { Karena kita dapat membantu } \\
\text { alam untuk menjadi lebih baik }\end{array}$ \\
\hline 3 & $\begin{array}{l}\text { Bisa membantu mengatasi } \\
\text { masalah di sekitar kita }\end{array}$ \\
\hline
\end{tabular}

Berdasarkan beberapa pernyataan yang dikemukakan siswa, pembelajaran ini dilakukan agar siswa dapat menyelesaikan permasalahan lingkungan berdasarkan pengetahuan yang mereka miliki (Febriasari \& Supriatna, 2017). Selain itu, pembelajaran ini juga dilakukan untuk menumbuhkan kesadaran lingkungan (Okur-Berberoglu, 2017). Salah satu bentuk pembelajaran terintegrasi pendidikan lingkungan yang dapat dilakukan untuk menumbuhkan kesadaran lingkungan yaitu melalui pembelajaran berbasis ecopedagogy.

Berdasarkan hasil angket yang diperoleh, dapat diketahui bahwa sebanyak $87,6 \%$ siswa tidak mengetahui istilah ecopedagogy. Ecopedagogy merupakan sebuah pendekatan dalam pembelajaran yang bertujuan untuk menumbuhkan kesadaran ekologis (Yunansah \& Herlambang, 2017). Sebanyak $94,8 \%$ siswa mengatakan bahwa mereka memiliki sikap peduli lingkungan. Sikap peduli lingkungan yang mereka miliki diantaranya kesadaran diri untuk membuang sampah di tempat sampah, upaya menghemat air, serta mengurangi penggunaan plastik. Siswa juga mengatakan bahwa sikap peduli lingkungan dapat ditumbuhkan melalui kegiatan pembelajaran. Kegiatan pembelajaran yang dimaksud adalah pembelajaran fisika berbasis ecopedagogy. Hal ini karena pembelajaran berbasis ecopedagogy tidak hanya bertujuan pada penguasaan konsep semata, tetapi juga meggambarkan permasalahan lingkungan serta menyelesaikan permasalahan tersebut dengan bantuan fisika (Napitupulu, 2015).

\section{SIMPULAN DAN SARAN}

Berdasarkan hasil penelitian yang telah dilakukan dapat diidentifikasi bahwa persepsi siswa terhadap pembelajaran fisika berbasis ecopedagogy adalah positif. Siswa tertarik dengan pembelajaran ini. Siswa juga menyatakan bahwa pembelajaran fisika berbasis ecopedagogy penting untuk dilakukan. Hal ini karena pembelajaran fisika berbasis ecopedagogy dilakukan dengan tujuan agar siswa dapat menyelesaikan berbagai permasalahan lingkungan berdasarkan konsep fisika yang dipahami. Selain itu, pembelajaran ini juga dapat menumbuhkan sikap kesadaran lingkungan.

Berdasarkan hasil penelitian dan pembahasan yang telah dilakukan, adapun saran yang dapat diberikan yaitu agar melakukan kegiatan pembelajaran fisika yang lebih bermakna. Kegiatan pembelajaran akan lebih bermakna apabila siswa merasakan pengalaman belajar secara langsung melalui praktik. Pembelajaran yang dilakukan dengan metode ceramah cenderung membuat siswa mengalami kesulitan belajar karena siswa hanya diberikan bekal teori dan pemahaman konsep saja. Melalui kegiatan praktik, siswa dapat menerapkan konsep yang mereka pahami dalam menyelesaikan permasalahan yang ada. Selain itu, penting dilakukan kegiatan pembelajaran fisika berbasis ecopedagogy karena pada pembelajaran ini siswa diajak untuk menerapkan konsep konsep fisika dalam menyelesaikan permasalahan lingkungan.

\section{DAFTAR RUJUKAN}

Agfar, A., Munandar, A., \& Surakusumah, W. (2018, May). Environmental literacy based on educational background. In Journal of Physics: Conference Series (Vol. 1013, No. 1, p. 012008). IOP Publishing.

Allo, M. D. G. (2020). Is the online learning good in the midst of Covid-19 Pandemic? The case of EFL learners. Jurnal Sinestesia, 10(1), 1-10.

Arief, M. K., Handayani, L., \& Dwijananti, P. (2012). Identifikasi kesulitan belajar fisika pada siswa RSBI : Studi kasus di RSMABI se Kota Semarang. UPEJ (Unnes Physics Education Journal), 1(2).

Azizah, R., Yuliati, L., \& Latifah, E. (2015). Kesulitan pemecahan masalah fisika pada siswa SMA. Jurnal Penelitian Fisika Dan Aplikasinya (JPFA), 5(2), 44-50.

Chang, C. L., \& Fang, M. (2020). E-Learning and online instructions of higher education during the 2019 novel 
coronavirus diseases (COVID-19) epidemic. Journal of Physics: Conference Series (Vol. 1574, No. 1, p. 012166). IOP Publishing.

Dewa, E., Mukin, M. U. J., \& Pandango, O. (2020). Pengaruh pembelajaran daring berbantuan laboratorium virtual terhadap minat dan hasil belajar kognitif fisika. Jurnal Riset Teknologi dan Inovasi Pendidikan (JARTIKA), 3(2), 351-359.

Febriasari, L. K., \& Supriatna, N. (2017, September). Enhance environmental literacy through problem based learning. In Journal of physics: conference series (Vol. 895, No. 1, p. 012163). IOP Publishing.

Grigorov, S. K., \& Fleuri, R. M. (2012). Ecopedagogy: educating for a new ecosocial intercultural perspective. Visao Global, 15(1), 433-454.

Haqiqi, A. K., \& Sa'adah, L. (2018). Deskripsi kesulitan belajar materi fisika pada siswa sekolah menengah pertama (SMP) di Kota Semarang. THABIEA: Journal Of Natural Science Teaching, 1(1), 39-43.

Hidayat, S. R., Setyadin, A. H., Hermawan, H., Kaniawati, I., Suhendi, E., Siahaan, P., \& Samsudin, A. (2017). Pengembangan instrumen tes keterampilan pemecahan masalah pada materi getaran, gelombang, dan bunyi. Jurnal Penelitian \& Pengembangan Pendidikan Fisika, 3(2), 157-166.

Khanafiyah, S., \& Yulianti, D. (2013). Model problem based instruction pada mengembangkan sikap kepedulian lingkungan. Jurnal Pendidikan Fisika Indonesia (Indonesian Journal of Physics Education), 9(1), 35-42.

Lase, D. (2019). Pendidikan di era revolusi industri 4.0. SUNDERMANN: Jurnal Ilmiah Teologi, Pendidikan, Sains, Humaniora Dan Kebudayaan, 12(2), 28-43.

Napitupulu, N. (2015). Pengembangan sikap ekologis melalui pembelajaran ecophysics berbasis ecopedagogy. Jurnal Inovasi dan Pembelajaran Fisika, 2(2), 113-119.

Napitupulu, N. D., \& Munandar, A. (2017, May). The effects of inquiry based ecopedagogy model on pre-service physics teachers' motivation and achievement in environmental physics instruction. In AIP Conference Proceedings (Vol. 1848, No. 1, p. 060004). AIP Publishing LLC.
Napitupulu, N. D., Munandar, A., Redjeki, S., \& Tjahyono, B. (2019, February). Interaction of students motivation and ecological phenomena toward learning outcomes using problem-based ecopedagogy. In Journal of Physics: Conference Series (Vol. 1157, No. 2, p. 022045). IOP Publishing $6596 / 1157 / 2 / 022045$.

Napsawati, N. (2020). Analisis situasi pembelajaran IPA Fisika dengan metode daring di tengah wabah covid19. Karst: Jurnal Pendidikan Fisika Dan Terapannya, 3(1), 6-12.

Okur-Berberoglu, E. (2017). Ecological dynamics model and ecopedagogybased outdoor experiential education. International Electronic Journal of Environmental Education, 7(2), 134151.

Purwanto, A., Ichsan, I. Z., Gomes, P. W. P., Rahman, M. M., \& Irwandani. (2020). Esbor during covid-19: Analysis students attitude for develop 21st century environmental learning. Journal of Sustainability Science and Management, 15(7), 20-29.

Sadikin, A., \& Hamidah, A. (2020). Pembelajaran daring di tengah wabah Covid-19. BIODIK, 6(2), 214-224.

Samudra, G., Suastra, M., \& Suma, M. (2014). Permasalahan-permasalahan yang dihadapi siswa SMA di Kota Singaraja dalam mempelajari fisika. Jurnal Pendidikan Dan Pembelajaran IPA Indonesia, 4(1).

Sukma, E., Ramadhan, S., \& Indriyani, V. (2020, March). Integration of environmental education in elementary schools. In Journal of Physics: Conference Series (Vol. 1481, No. 1, p. 012136). IOP Publishing.

Suryanti, D., Sinaga, P., \& Surakusumah, W. (2018, February). Improvement of students' environmental literacy by using integrated science teaching materials. In IOP Conference Series: Materials Science and Engineering (Vol. 306, No. 1, p. 012031). IOP Publishing.

Trianggono, M. M. (2017). Analisis Kausalitas Pemahaman Konsep Dengan Kemampuan Berpikir Kreatif Siswa Pada Pemecahan Masalah Fisika. Jurnal Pendidikan Fisika Dan Keilmuan (JPFK), 3(1), 1-12.

Yalmanci, S.G, \& Gözüm, A. I. C. (2019). The study of whether receiving a pre-school education is a predictive factor in the attitudes of high school students toward 
the environment according to their environmental ethics approach. International Electronic Journal of Environmental Education, 9(1), 18-32.

Yunansah, H., \& Herlambang, Y. T. (2017). Pendidikan Berbasis Ekopedagogik Dalam Menumbuhkan Kesadaran Ekologis Dan Mengembangkan Karakter Siswa Sekolah Dasar. EduHumaniora| Jurnal Pendidikan Dasar Kampus Cibiru, 9(1), 27-34. 